\title{
Pengaruh Kebijakan Dividen, Laba dan Arus Kas pada Harga Saham Perusahaan LQ45 Periode 2014-2016
}

\author{
Arya Bagus Govinda Tedja Bhuana ${ }^{1}$ \\ I G.N. Agung Suaryana ${ }^{2}$ \\ ${ }^{1}$ Fakultas Ekonomi dan Bisnis Universitas Udayana (Unud), Bali, Indonesia \\ email: aryabagus1997@gmail.com / Telp: 081239015003 \\ ${ }^{2}$ Fakultas Ekonomi dan Bisnis Universitas Udayana (Unud), Bali, Indonesia
}

\begin{abstract}
ABSTRAK
Investasi merupakan suatu hal yang pada umumnya agar bertambah harta yang dimiliki oleh masyarakat.Perkembangan indikator-indikator di pasar modal sendiri, seperti indeks LQ45 ini berisi emiten-emiten yang memiliki likuiditas yang tinggi, sehingga tingkat kepercayaan investor pun semakin tinggi untuk menanamkan modalnya pada bursa efek. Tujuan penelitian ini untuk mengujipengaruh kebijakan dividen,pengaruh labadan pengaruh arus kas pada harga saham. Penelitian ini mengambil sampel berdasarkan metode non probability sampling dengan teknik sampling jenuh pada perusahaan yang tercatat di Bursa Efek Indonesia dengan jumlah populasi sebanyak 99 populasi dan jumlah sampel 72 observasian. Teknik analisis data yang digunakan dalam penelitian ini menggunakan analisis regresi linier sederhana dan analisis regresi linier berganda. Hasil penelitian mengungkapkan bahwa kebijakan dividen yang diproksikan dengan dividend payout ratio berpengaruh positif, laba yang menggunakan laba komprehensif berpengaruh positif sedangkan arus kas yang menggunakan arus kas operasi tidak berpengaruh pada harga saham.
\end{abstract}

Kata Kunci: Investasi, pasar modal, indeks LQ45,kebijakan dividen, laba, arus kas.

\begin{abstract}
Investment is a common thing to increase the property owned by the community. LQ45 index contains the issuers that have high liquidity, so the level of investor confidence is higher to invest in the stock exchanges. The purpose of this study to examine the influence of dividend policy, the effect of earnings and the influence of cash flows on stock prices. This study took a sample based on non-probability sampling method with saturated sampling technique at companies listed on the Indonesia Stock Exchange with a population of 99 populations and a total sample of 72 observations.Data analysis techniques used in this study using simple linear regression analysis and multiple linear regression analysis. The result of the research revealed that dividend payout ratio policy has positive effect, profit using comprehensive profit has positive effect while cash flow using cash flow operation does not affect stock price.

Keywords: investment, capital market, LQ45 index, dividend policy, profit, cash flow.
\end{abstract}

\section{PENDAHULUAN}

Investasi merupakan suatu aktivitas yang pada umumnya salah satu cara dalam mengembangkan jumlah uang atau harta atau aset yang dimiliki pada saat ini dengan harapan mendapatkan keuntungan di masa depan (Gitman dan Joehnk, 2005:3). Macam-macam instrumen investasi yang ada di masyarakat pada 
umumnya hanya berkisar pada instrumen-instrumen yang umum dan telah banyak dikenal seperti tanah, rumah, emas, deposito. Seiring dengan berkembangnya zaman, maka perkembangan di bidang keuangan khususnya di bidang investasi pun semakin marak. Salah satu tempat untuk melakukan investasi adalah di pasar modal. Pasar modal dibangun dengan tujuan menggerakan perekonomian suatu negara melalui kekuatan swasta dan mengurangi beban Negara (Antolis dan Dossugi, 2008). Terdapat beberapa macam indeks-indeks yang di publikasikan oleh Bursa Efek Indonesia di pasar modal, diantaranya adalah IHSG, LQ45, JII, MBX，DBX，KOMPAS100，BISNIS-27，PEFINDO25，SRI-KEHATI，ISSI, INFOBANK15, SMINFRA18, Indeks IDX30 (www.idx.co.id). Indeks-indeks yang terdapat dalam pasar modal dapat dijadikan acuan (benchmark) atau indikator yang menggambarkan pergerakan saham. Dalam pasar modal sebuah indeks diharapkan memiliki lima fungsi, yaitu sebagai indikator trend pasar, sebagai indikator tingkat keuntungan, sebagai acuan kinerja suatu portofolio, memfasilitasi pembentukan portofolio dengan strategi pasif, memfasilitasi berkembangnya produk derivatif (Darmadji et al., 2001).

Perkembangan indikator-indikator di pasar modal sendiri, seperti indeks LQ45 ini merupakan indeks yang didalamnya terdapat emiten-emiten yang memiliki likuiditas yang tinggi, sehingga tingkat kepercayaan investor pun semakin tinggi untuk menanamkan modalnya pada bursa efek, dan pada akhirnya akan meningkatkan angka indeks LQ45 ini. Dalam melakukan investasi di pasar modal, harga saham tidak terlepas dari banyak faktor yang mempengaruhi pasar saham itu sendiri. Faktor-faktor tersebut diantaranya faktor lingkungan internal 
yang berasal dari dalam perusahaan. Informasi yang didapat dari faktor internal perusahaan tersebut sangat penting dalam memprediksi harga saham.

Kebijakan dividen merupakan bagian yang tidak dapat dipisahkan dengan keputusan pendanaan perusahaan. Kebijakan dividen (dividend policy) merupakan keputusan apakah laba yang diperoleh oleh suatu perusahaan pada akhir tahun akan dibagikan kepada pemegang saham dalam bentuk dividen atau akan ditahan untuk menambah modal guna pembiayaan investasi oleh perusahaan di masa yang akan datang (Ardiprawiro:121).

Kebijakan dividen sangat penting karena mempengaruhi kesempatan investasi perusahaan, harga saham, struktur finansial, arus pendanaan dan posisi likuiditas. Dengan perkataan lain, kebijakan dividen menyediakan informasi mengenai performa (performance) perusahaan. Masing-masing perusahaan menetapkan kebijakan dividen yang berbeda-beda, karena kebijakan dividen berpengaruh terhadap nilai perusahaan dalam membayar dividen kepada para pemegang sahamnya, maka perusahaan mungkin tidak dapat mempertahankan dana yang cukup untuk membiayai pertumbuhannya di masa mendatang. Sebaliknya, maka saham perusahaan menjadi tidak menarik bagi perusahaan. Peranan seorang manajer keuangan sangat penting dalam memutuskan apakah kebijakan yang diambil oleh perusahaan baik bagi nilai perusahaan dimasa mendatang di mata para investor (Nurmala, 2006).

Salah satu karakteristik kualitatif dari informasi laba adalah nilai kemampuannya dalam memprediksi harga saham. Reaksi pasar terhadap harga saham tercermin dalam pergerakan harga saham di sekitar tanggal pengumumam 
informasi laba (Junaidi, 2015). Harga saham cenderung naik apabila laba yang dilaporkan lebih besar dan sebaliknya dan informasi lain yang di butuhkan oleh pelaku pasar modal adalah laporan arus kas. Laporan arus kas memberikan informasi yang memungkinkan para pemakai untuk mengevaluasi perubahan dalam aktiva bersih perusahaan, struktur keuangan. Laba akuntansi memiliki potensi sebagai prediktor karena laba akuntansi mempunyai kandungan informasi terhadap harga saham. Selain itu laba akuntansi juga mempunyai kandungan informasi yang relavan bagi investor dan merupakan kunci informasi penting dalam pengambilan keputusan.

Melihat fakta bahwa pergerakan harga saham pada perusahaan yang tersedia di bursa efek Jakarta yang dari hari kehari bergerak fluktuatif khususnya dalam indeks saham LQ45 yang diakibatkan oleh faktor seperti faktor variabel internal perusahaan dan berdasarkan hasil penelitian-penelitian terdahulu maka peneliti akan meneliti: "Pengaruh Kebijakan Dividen, Laba dan Arus Kas pada Harga Saham Perusahaan LQ45 Periode 2014-2016" Rumusan masalah yang dapat diajukan yaitu(1) apakah kebijakan dividen berpengaruh pada harga saham? (2) apakah laba berpengaruh pada harga saham? (3) apakah arus kas berpengaruh pada harga saham? Tujuan penelitian inidiharapkan dapatmendapatkan bukti empiris mengenai pengaruh kebijakan dividen, laba dan arus kas pada harga saham. Penelitian ini juga diharapkan mampu memberikan kegunaan berupa kontribusi yang mendukung teori sinyal dengan fenomena yang berhubungan dengan pengaruh variabel internal perusahaan terhadap harga saham. Penelitian ini juga bertujuan untuk memberikan informasi dalam pengembangan keputusan 
dalam melakukan transaksi di pasar modal. Kegunaan praktis dari penelitian ini adalah memberikan referensi tambahan kepada manajemen perusahaan, pengguna laporan kuangan, investor serta masyarakata umum tentang bagaimana kebijakan yang akan diambil dalam keputusan melakukan transaksi di pasar modal.

Teori sinyal menyatakan bahwa perusahaan yang berkualitas baik dengan sengaja akan memberikan sinyal pada pasar, dengan demikian pasar diharapkan dapat membedakan perusahaan yang berkualitas baik dan buruk. Jama'an (2008) mengemukakan tentang sikap perusahaan kepada pengguna laopran keuangan. Sinyal ini berupa informasi mengenai apa yang sudah dilakukan oleh manajemen untuk merealisasikan keinginan pemiliknya. Hal ini berprinsip bahwa akan mencegah perusahaan melakukan tindakan yang membesar-besarkan laba dan dapat membantu pengguna laporan keuangan dengan menyajikan laba dan aktiva yang tidak overstate.

Pengumuman pembayaran dividen oleh manajemen perusahaan adalah Sinyal bagi investor. Manajemen ingin menunjukkan bahwa mereka mampu memenuhi pembayaran dividen kepada pemegang saham. Hal ini secara tidak langsung memberikan sinyal bahwa konmdisi perusahaan sangat kuat sehingga mampu membagikan dividen. Dividen kemudian menjadi alat ukur bagi investor untuk menilai kinerja keuangan perusahaan dan prospeknya dimasa mendatang (Bhattacharya, 1979), yang kemudian Schneeman (2012:435) menjelaskan bahwa dividen adalah pembayaran kepada pemegang saham dari keuntungan sebuah perusahaan sebagai laba atas investasi pemegang saham, merupakan sebuah sinyal 
Arya Bagus Govinda Tedja Bhuana dan I G.N Agung Suaryana. Pengaruh...

bagi para pemegang saham yang dikeluarkan oleh perusahaan, karena perusahaan tersebut melalukan pembayaran yang berupa dividen.

Samsul (2006:43) pasar modal adalah tempat atau sarana bertemunya antara permintaan dan penawaran atas instrumen keuangan jangka panjang. Hukum mendefinisikan pasar modal sebagai "Kegiatan yang bersangkutan dengan penawaran umum dan perdagangan efek, perusahaan publik yang berkaitan dengan penawaran umum dan perdagangan efek, perusahaan publik yang berkaitan dengan efek yang diterbitkannya, serta lembaga dan profesi yang berkaitan dengan efek".Bursa efek atau Stock Exchange adalah suatu sistem yang terorganisasi yang mempertemukan penjual dan pembeli efek yang dilakukan baik secara langsung maupun dengan melalui wakil wakilnya. Fungsi bursa efek ini antara lain adalah menjaga kontinuitas pasar dan menciptakan harga efek yang wajar melalui mekanisme permintaan dan penawaran. Terdapat dua analisis yang banyak digunakan untuk menentukan harga saham yakni analisis teknikal dan analisis fundamental. Nilai dalam suatu saham ada bermacam-macam diantaranya nilai buku yang menunjukkan aktiva bersih yang dimiliki pemegang saham. Kemudian nilai pasar yang menunjukkan harga saham yang terjadi di pasar bursa pada saat tertentu yang ditentukan oleh pelaku pasar. Sedangkan nilai intrinsic merupakan nilai saham yang menentukan harga wajar suatu saham agar saham tersebut mencerminkan nilai saham yang sebenarnya.

Menurut Subramanyam (2008:408) laba (income - juga disebut earnings atau profit) merupakan:"ringkasan hasil aktivitas operasi usaha yang dinyatakan dalam istilah keuangan. Laba merupakan informasi perusahaan yang paling 
diminati di pasar modal. Laba merupakan pengukuran atas perubahan kekayaan pemegang saham (perubahan nilai) maupun merupakan estimasi laba masa depan”. Yocelyn dan Jogi Christiawan (2012) menyebutkan laba didefinisikan sebagai perbedaan antara pendapatan yang direalisasikan dari transaksi yang terjadi selama satu periode dengan biaya yang berkaitan dengan pendapatan tersebut.

Laporan arus kas merupakan laporan utama yang menyajikan informasi mengenai penerimaan kas, pembayaran kas dan hasil perubahan dalam nilai bersih dari aktivitas operasi, aktivitas investasi dan aktivitas pendanaan pada suatu periode tertentu. Kieso, et al (2011). Arus kas berguna untuk memberikan informasi mengenai penerimaan dan pembayaran atau suatu satuan selama satu periode. Laporan arus kas dapat menyediakan informasi yang memungkinkan pengguna untuk mengevaluasi perubahan dalam asset neto entitas, struktur keuangannya dan kemampuannya untuk mempengaruhi jumlah serta waktu arus kas dalam rangka penyesuaian terhadap keadaan dan peluang yang berubah. (Ikatan Akuntansi Indonesia PSAK No. 2, 2015). Arus kas operasi mencangkup pengaruh kas dari transaksi yang menghasilkan pendapatan dan beban, kemudian dimasukkan dalam penentuan laba bersih. Jumlah arus kas yang berasal dari aktivitas operasi sendiri merupakan indikator yang menentukan apakah operasi perusahaan dapat menghasilkan arus kas yang cukup untuk melunasi pinjaman, memelihara kemampuan operasi perusahaan, membayar dividen, dan melakukan investasi baru tanpa mengandalkan sumber pendanaan dari luar. 
Arya Bagus Govinda Tedja Bhuana dan I G.N Agung Suaryana. Pengaruh...

Kebijakan dividen merupakan cara pembagian dividen kepada para pemegang saham yang dilakukan oleh suatu perusahaan, penyebutan pembagian dividen tersebut diumumkan pada saat Rapat Umum Pemegang Saham Tahunan (RUPST) diselenggarakan. Kebijakan dividen ini akan memengaruhi para investor dan persepsinya di pasar modal, adanya kebijakan dividen secara tidak langsung memberikan informasi bahwa manajer dapat mengelola perusahaan dengan adanya peningkatan jumlah dividen bagi para investor. Hubungan teori sinyal dengan penelitian ini menunjukkan bahwa kebijakan dividen sering dianggap sebagai sinyal bagi investor dalam menilai baik buruknya perusahaan, hal ini disebabkan karena kebijakan dividen dapat membawa pengaruh terhadap harga saham perusahaan.

Istanti (2013) dalam penelitiannya menyatakan, bahwa kebijakan dividen berpengaruh dan menunjukkan arah yang positif dimana bahwa semakin besar dividen payout ratioakan membuat harga saham meningkat. Penelitian tersebut didukung oleh beberapa penelitian dari Majanga (2015) yang menyatakan bahwa adanya pengaruh dan hubungan yang positif antara kebijakan dividen dengan harga saham, Sharif et al (2015) yang menyatakan, bahwa kebijakan dividen berpengaruh positif terhadap harga saham, namun hasil penelitian yang berbeda ditemukan dalam penelitian Fernandus (2015) dan Topowijono (2016) yang menyatakan dividen tidak berpengaruh terhadap harga saham. Berdasarkan uraian diatas, maka dapat dirumuskan hipotesis penelitian sebagai berikut:

$\mathrm{H}_{1}$ : Kebijakan dividen berpengaruh positif pada harga saham. 
Laba merupakan data yang sangat penting baik bagi investor. Ketika investor memutuskan untuk membeli atau menjual saham, investor memerlukan informasi, salah satunya adalah laba perusahaan (Maharani, 2014). Teori sinyal yang menyatakan bahwa informasi yang dipublikasikan sebagai suatu pengumuman akan memberikan signal bagi investor dalam pengambilan keputusan investasi. Pada saat informasi diumumkan, pelaku pasar terlebih dahulu menginterpretasikan dan menganalisis informasi tersebut sebagai signal baik (good news) atau signal buruk (bad news) Jogiyanto (2008). Berkaitan dengan laba yang dihasilkan perusahaan, tentang apabila perusahaan menghasilkan laba, dan tidak rugi merupakan sebuah sinyal yang baik (good news) bagi pihak eksternal.

Pengawasan Penelitian Ball dan Brown (1968) menduga manfaat keberadaan angka laba akuntansi dengan menguji kandungan informasi dan ketepatan waktu dari angka laba tersebut. Mereka menemukan bahwa informasi yang terkandung dalam angka akuntansi adalah berguna yaitu jika laba yang sesungguhnya berbeda dengan laba ekspektasi (expected earning) maka pasar akan bereaksi yang tercermin dalam pergerakan harga saham sekitar tanggal pengumuman informasi laba. Harga saham cenderung naik apabila laba yang dilaporkan lebih besar dari laba ekspektasi dan sebaliknya, harga saham cenderung turun apabila laba yang dilaporkan lebih kecil dari laba ekspektasi. Ball dan Brown (dalam Mutia, 2012). Mutia (2012), dalam penelitiannya menyatakan bahwa laba berpengaruh positif pada harga saham, Penelitian tersebut didukung juga oleh penelitian yang dilakukan oleh Marlyana (2014) dan Penelitian yang 
dilakukan oleh Asrianti (2015) yang menyatakan bahwa laba berpengaruh positif dan dapat menjadi indikator dalam memprediksi harga saham, karena perusahaan yang mempublikasikan informasinya yang yang mengandung nilai positif tentu akan menjadi sinyal yang baik bagi pihak eksternal. Berdasarkan uraian diatas, maka dapat dirumuskan hipotesis penelitian sebagai berikut:

$\mathrm{H}_{2}$ : laba berpengaruh positif pada harga saham.

Arus kas dari aktivitas operasi yang cukup, memungkinkan perusahaan untuk tidak perlu mengandalkan pembiayaan dari luar (penerbitan saham atau utang kepada pihak eksternal) dan informasi tersebut menjadikan juga sebuah good news oleh pihak eksternal, karena perusahaan tidak terlalu perlu mengandalkan pembiayaan dari luar, sehingga struktur modal yang dimiliki oleh perusahaan tetap dan dana yang diinvestasikan oleh investor dikelola secara efektif dan efisien oleh perusahaan,tentu saja hal tersebut akan meningkatkan nilai perusahaan dimata investor, dengan demikian investor akan tertarik untuk berinvestasi (Djago, 2016) dan dalam penelitian Marlyana (2014) juga menyatakan bahwa arus kas operasi berpengaruh terhadap harga saham. Berdasarkan uraian diatas maka dapat dirumuskan hipotesis penelitian sebagai berikut:

$\mathrm{H}_{3}$ : Arus kas operasi berpengaruh positif pada harga saham.

\section{METODE PENELITIAN}

Penelitian ini, pendekatan yang digunakan adalah pendekatan kuantitatif yang bersifat asosiatif. Pendekatan kuantitatif merupakan metode penelitian yang berdasarkan pada filsafat positivisme yang digunakan untuk meneliti pada 
populasi dan sampel tertentu yang bertujuan untuk menguji hipotesis yang telah ditetapkan (Sugiyono, 2014:13). Sedangkan penelitian asosiatif yaitu penelitian yang bertujuan untuk mengetahui hubungan antara dua variabel atau lebih (Sugiyono, 2014:55). Pada penelitian ini, variabel yang digunakan adalah kebijakan dividen, laba, dan arus kasoperasi sebagai variabel independen, dan harga Saham yang dibagi menjadi 2 yaitu: pada saat setelah Rapat Umum Pemegang Saham Tahunan (RUPST) dan pada saat publikasi laporan keuangan sebagai variabel dependen.

Penelitian ini dilakukan pada harga saham perusahaan yang menetap dalam indeks LQ45 yang terdaftar di Bursa Efek Indonesia (BEI) pada tahun 2014-2016 dengan mengakses situs resmi Bursa Efek Indonesia (www.idx.co.id). Obyek dalam penelitian ini adalah kebijakan dividen, laba dan arus kas operasi pada harga saham. Variabel terikat dalam penelitian ini adalah harga saham pada saat setelah RUPST $\left(\mathrm{Y}_{1}\right)$ dan harga saham pada saat setelah publikasi laporan keuangan $\left(\mathrm{Y}_{2}\right)$. Sedangkan variabel bebas dalam penelitian ini adalah kebijakan dividen $\left(\mathrm{X}_{1}\right)$, laba $\left(\mathrm{X}_{2}\right)$ dan arus kas operasi $\left(\mathrm{X}_{3}\right)$.

Harga saham adalah harga suatu saham yang terjadi di pasar bursa pada saat tertentu yang ditentukan oleh pelaku pasar dan ditentukan oleh permintaan dan penawaran saham yang bersangutan di pasar modal. Harga saham yang digunakan disini merupakan harga saham perusahaan yang terdapat dalam indeks saham LQ45 pada saat penutupan (closing price) pada periode pengamatan yang menyesuaikan dengan tanggal publikasi laporan keuangan perusahaan di Bursa 
Efek Indonesia dan harga saham saat setelah diumumkannya dividen pada tanggal RUPST (Rapat Umum Pemegang Saham Tahunan) dilaksanakan, karena untuk meneliti pengaruh laba dan arus kas perlu menggunakan harga saham pada saat setelah tanggal publikasi laporan keuangan, sedangkan dibutuhkan harga saham pada saat setelah diumumkannya RUPST untuk meneliti apakah harga saham dapat dipengaruhi oleh kebijakan dividen. Data-data tersebut dapat diakses melalui situs resmi Bursa Efek Indonesia (www.idx.co.id) ataupun situs resmi yahoo finance (https://finance.yahoo.com).

Dividend Policy atau kebijakan dividen adalah keputusan perusahaan yang berhubungan dengan pembayaran dividen oleh perusahaan pada saat Rapat Umum Pemegang Saham Tahunan (RUPST).Kebijakan dividen merupakan cara pembagian dividen kepada para pemegang saham yang dilakukan oleh suatu perusahaan, proksi yang digunakan untuk mengukurnya yaitu dengan menggunakan Dividen Payout Ratio (DPR) yang merupakan pembayaran dividen kepada para pemegang saham atas laba bersih yg dimiliki perusahaan, dan dihitung dengan rumus:

$$
\text { Dividend Payout Ratio }(\text { DPR })=\frac{\text { Dividend }}{\text { Net Profit }}
$$

Subramanyam (2010:109) menjelaskan bahwa laba merupakan ringkasan hasil bersih aktivitas operasi usaha dalam periode tertentu yang dinyatakan dalam istilah keuangan. Data mengenai laba Komprehensif tahun berjalan perusahaan yang terdaftar dalam indeks saham LQ45 dapat diakses melalui laporan keuangan yang telah diaudit dan dipublikasi di situs resmi Bursa Efek Indonesia (www.idx.co.id). 
Arus kas yang berasal dari aktivitas operasi adalah aktivitas penghasil utama pendapatan entitas dan aktivitas lain yang bukan merupakan aktivitas investasi dan aktivitaas pendanaan. Arus kas yang digunakan dalam penelitian ini yaitu arus kas operasi, dimana jumlah yang timbul dari aktivitas operasi adalah indikator utama untuk menentukan apakah operasi entitas telah menghasilkan arus kas yang cukup untuk melunasi pinjaman, memelihara kemampuan operasi entitas, membayar dividen, dan melakukan investasi baru tanpa sumber pendanaan dari luar. Data mengenai arus kas operasi perusahaan yang terdaftar dalam indeks saham LQ45 dapat diakses melalui laporan keuangan yang terlah diaudit dan dipublikasi di situs resmi Bursa Efek Indonesia (www.idx.co.id).

Dalam penelitian ini yang menjadi populasi adalah seluruh data time series perusahaan yang terdaftar konsisten dalam indeks saham LQ45 dari Bursa Efek Indonesia (BEI) periode tahun 2014-2016 dan Bank Indonesia (BI). Sampel dalam penelitian ini adalah perusahaan yang terdaftar konsisten dalam indeks saham LQ45 di Bursa Efek Indonesia (BEI) periode 2014-2016. Pemilihan perusahaan di Bursa Efek Indonesia (BEI) dikarenakan pertimbangan kemudahan akses data dan informasi, serta biaya dan waktu. Selain itu dalam penelitian ini menggunakan rentang waktu penelitian selama tiga tahun pengamatan yaitu tahun 2014-2016 untuk mendapatkan data terbaru yang mendukung dalam melakukan penelitian. Metode penentuan sampel (sampling method) yang digunakan dalam penelitian ini adalah teknik non-probability sampling dengan metode sampel jenuh, karena diduga populasi yang akan digunakan relatif kecil. Teknik sampel jenuh 
Arya Bagus Govinda Tedja Bhuana dan I G.N Agung Suaryana. Pengaruh...

merupakan teknik penentuan sampel bila semua anggota populasi digunakan sebagai sampel (Sugiyono, 2014:58).

\section{HASIL DAN PEMBAHASAN}

Lokasi penelitian ini dilakukan di perusahaan yang terdaftar dalam indeks saham LQ45 yang merupakan indeks saham yang tercatat di dalam Bursa Efek Indonesia (BEI) periode 2014-2016 dengan memeroleh data melalui alamat website BEI (www.idx.co.id). Sampel yang digunakan dalam penelitian adalah sebanyak 33 perusahaan selama tiga tahun dengan total observasian sebanyak 99 data observasian dan terdapat data yang dioutlier dikarenakan data tersebut terdeteksi tidak normal dalam pengolahannya di aplikasi pengolahan data SPSS.

\section{Tabel 1.}

\section{Penentuan Jumlah Sampel}

\begin{tabular}{llrr}
\hline No. & Keterangan & Jumlah & Akumulasi \\
\hline $\begin{array}{l}\text { 1. } \\
\quad \text { Perusahaan yang secara konsisten terdaftar di indeks saham } \\
\quad \text { periode 2016. }\end{array}$ & 33 & 99 \\
$\quad$ Data outlier & & \\
2. & $(9)$ & (27) \\
Jumlah observasian yang memenuhi kriteria selama periode 2012- & 24 & 72 \\
2016 & & \\
Sumber : Data diolah, 2018
\end{tabular}

Statistik deskriptif digunakan untuk mengetahui jumlah sampel, nilai minimum, nilai maksimum, nilai rata-rata, dan standar deviasi dari masing-masing variabel.

Tabel 2.

Hasil Uji Statistik Deskriptif

\begin{tabular}{|c|c|c|c|c|c|}
\hline & $\mathbf{N}$ & Minimum & Maximum & Mean & $\begin{array}{c}\text { Std. } \\
\text { Deviation }\end{array}$ \\
\hline Y1 & 72 & ,334 & 8,575 & 2,921 & 2,015 \\
\hline $\mathrm{X} 1$ & 72 & ,000 & ,500 & ,278 & ,133 \\
\hline Y2 & 72 & ,348 & 8,600 & 2,953 & 2,039 \\
\hline $\mathrm{X} 2$ & 72 &, 252 & 41,380 & 6,238 & 9,642 \\
\hline $\mathrm{X} 3$ & 72 & $-7,762$ & 84,930 & 7,561 & 15,122 \\
\hline
\end{tabular}


Berdasarkan tabel 2, Nilai rata-rata harga saham setelah RUPST (Y1) sebesar 2,92 dengan standar deviasi sebesar 2,01, sedangkan nilai minimum sebesar 334 rupiah dimiliki oleh perusahaan ASRI dan nilai maksimum sebesar 8,575 rupiah dimiliki oleh perusahaan ASII. Nilai rata-rata kebijakan dividen yang diproksikan dengan Dividend Payout Ratio (X1) sebesar 0,27 dimana ratarata sebesar $27 \%$ akan dibagikan sebagai dividen kepada para pemegang saham atas laba yang dihasilkan dengan standar deviasi sebesar 0,13 , sedangkan nilai minimum sebesar 0 persen dimiliki oleh perusahaan ASRI dan nilai maksimum sebesar 0,5 persen dimiliki oleh ADRO. Nilai rata-rata harga saham setelah tanggal publikasi laporan keuangan (Y2) sebesar 2,95 dengan standar deviasi sebesar 2,03, sedangkan nilai minimum sebesar 348 rupiah dimiliki oleh perusahaan ASRI dan nilai maksimum sebesar 8600 rupiah dimiliki oleh perusahaan ASII. Nilai rata-rata laba komprehensif perusahaan (X2) sebesar 6,23 dengan standar deviasi sebesar 9,64, sedangkan nilai minimum sebesar 252 miliar rupiah dimiliki oleh perusahaan BMTR dan nilai maksimum SIZE sebesar 41,380 triliun rupiah dimiliki oleh perusahaan BBRI. 5) Nilai rata-rata arus kas operasi perusahaan (X3) sebesar 7,56 dengan standar deviasi sebesar 15,12, sedangkan nilai minimum sebesar $-7,76$ triliun rupiah dimiliki oleh perusahaan WSKT dan nilai maksimum sebesar 84,930 triliun rupiah dimiliki oleh perusahaan BBRI.

Selanjutnya dilakukan uji asumsi klasik yang meliputi uji normalitas, uji autokorelasi, uji multikolinearitas dan uji heteroskedastisitas untuk mengetahui apakah data dalam penelitian yang dilakukan telah lolos dari asumsi klasik. Uji 
yang pertama adalah uji normalitas. Berdarkan uji yang dilakukan dipeoleh hasil uji normalitas kebijakan dividen pada harga saham setelah tanggal RUPST dan laba komprehensif adalah sebesar 0,200 dengan taraf signifikansi > 0,05 menunjukkan bahwa data penelitian ini dapat dikatakan berdistribusi normal. Kemudian hasil uji normalitas arus kas operasi pada harga saham setelah tanggal publikasi laporan keuangan adalah sebesar 0,200 dengan taraf signifikansi > 0,05 menunjukkan bahwa data penelitian ini dapat dikatakan berdistribusi normal.

Uji asumsi klasik yang kedua adalah uji autokorelasi. Berdasarkan hasil uji autokorelasi, nilai dw yang dihasilkan sebesar 1,75. Jumlah sampel sebanyak 72 dan terdapat 2 variabel yang diuji, maka nilai du sebesar 1,57 dan nilai $4-\mathrm{du}$ adalah 2,43. Dapat disimpulkan bahwa tidak adanya gejala autokorelasi pada data penelitian ini karena nilai dw berada di antara nilai du dan $4-$ du.

Uji selanjutanya yaitu uji multikolinearitas. Uji multikolinearitas bertujuan untuk menguji apakah model regresi ditemukan adanya korelasi antara variabel bebas. Untuk menguji multikolinearitas dengan cara melihat nilai tolerance dan Variance Inflation Factor (VIF) masing-masing variabel independen, laba komprehensif $\left(\mathrm{X}_{2}\right)$ dan arus kas operasi $\left(\mathrm{X}_{3}\right)$ dimana nilainya masing-masing sebesar 0,345 untuk tolerance dan 2,896 untuk VIF. Berdasarkan hasil uji ini, dapat dilihat bahwa nilaitolerance danVIF dari seluruh variabel menunjukkanbahwa nilai tolerance untuk setiapvariabel lebih besar dari $10 \%$ dan nilai VIF lebih kecil dari 10 yang berartimodel persamaanregresi bebas dari multikolinearitas. 
Uji asumsi klasik yang digunakan selanjutnya adalah uji heteroskedastisitas.bertujuan menguji apakah dalam model regresi terjadi ketidaksamaan variance dari residual satu pengamatan ke pangamatan yang lain. Uji statistik Glejser dipilih karena lebih dapat menjamin keakuratan hasil dibandingkan dengan uji grafik plot yang dapat menimbulkan bias. Berdasarkan hasil uji heteroskedastisitas, dapat diketahui nilai signifikansi dari variabel kebijakan dividen sebesar 0,592 (>0,05), nilai signifikansi dari variabel laba sebesar 0,282 (>0,05), dan nilai signifikansi dari variabel arus kas yakni sebesar 0,927 (>0,05). Oleh karena nilai signifikansi dari masing-masing variabel independen terhadap variabel absoluteresidual berada diatas 0,05 maka dapat disimpulkan bahwa data yang digunakan pada penelitian ini tidak terdapat masalah heteroskedastisitas.

\section{Tabel 3}

Hasil Uji Analisis Regresi Linier Sederhana

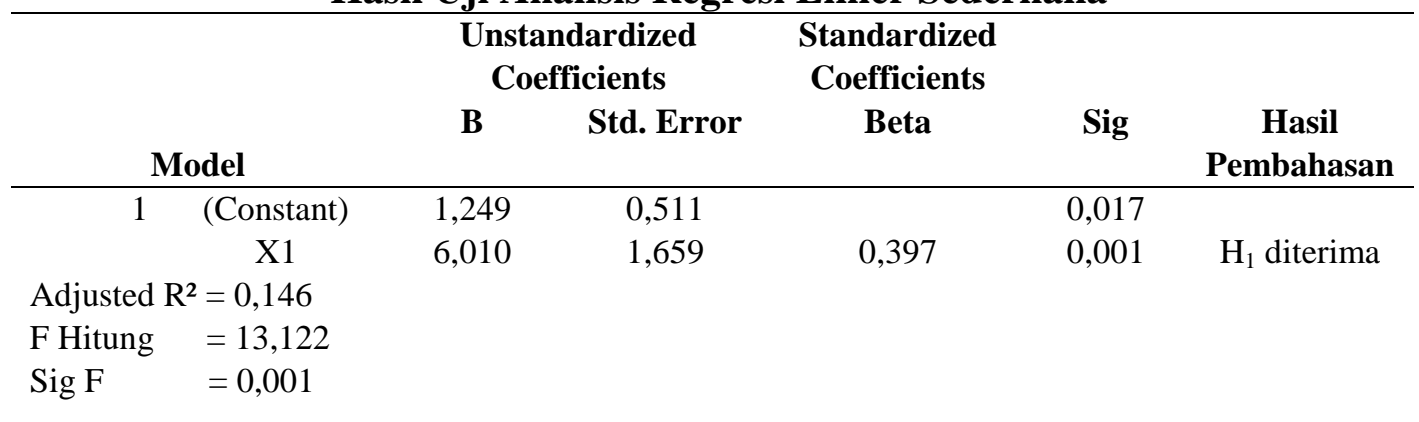

Sumber: Data diolah, 2018

Berdasarkan hasil yang diperoleh dari rekapitulasi hasil analisis regresi linear sederhana berdasarkan pada hasil analisis koefisien regresi pada Tabel 3 adalah sebagai berikut:

$$
Y=1,249+6,010 X_{1}+e
$$


Arya Bagus Govinda Tedja Bhuana dan I G.N Agung Suaryana. Pengaruh...

Nilai konstanta sebesar 1,249 memiliki arti apabila variabel independen konstan yang dimana variabel independen tersebut adalah kebijakan dividend yang diproksikan dengan Dividend Payout Ratio tersebut, maka harga saham setelah tanggal RUPST naik sebesar 1,249 persen. Nilai koefisien regresi $\mathrm{X}_{1}$ yang merupakan kebijakan dividen itu sendiri yang diproksikan dengan Dividend Payout Ratio sebesar 6,010 memiliki arti jika kebijakan dividen yang diproksikan dengan Dividend Payout Ratio meningkat sebesar 1 persen, maka harga saham setelah tanggal RUPST akan meningkat sebesar 6,010 persen dengan asumsi variabel independen lainnya konstan.

Berdasarkan Tabel 3 diatas maka dapat dilihat juga nilai koefisien determinasi $\left(\mathrm{R}^{2}\right)$, uji kelayakan model (uji $\mathrm{F}$ ), dan uji hipotesis (uji t) sebagai berikut. Koefisien determinasi $\left(\mathrm{R}^{2}\right)$ diukur untuk mengetahui persentase pengaruh variabel independen terhadap perubahan variabel dependen. Pada Tabel 3 nilai adjusted $\mathrm{R}^{2}$ sebesar 0,146 atau 14,6 persen. Hal ini berarti bahwa variabel harga saham setelah tanggal RUPST dapat dijelaskan sebesar 14,6 persen oleh variabel kebijakan dividend yang diproksikan dengan Dividend Payout Ratio sedangkan sisanya sebesar 85,4 persen dipengaruhi oleh variabel lain. Uji kelayakan model (Uji F) digunakan untuk mengetahui apakah model analisis regresi linier sederhana dalam penelitian ini layak digunakan. Pada Tabel tersebut nilai F hitung sebesar 13,122 dengan nilai signifikansi 0,001. Nilai signifikansi tersebut lebih kecil dari level signifikansi 0,05. Jadi dapat disimpulkan bahwa model analisis regresi linier sederhana ini layak digunakan. 
Hasil pengujian menggunakan regresi linier sederhana menunjukkan bahwa tingkat signifikansi sebesar 0,001 lebih kecil dari (5\%) dan koefisien regresi kebijakan dividen yang diproksikan dengan Dividend Payout Ratio sebesar 6,010, sesuai dengan hipotesis yang diharapkan sehingga $\mathrm{H}_{1}$ dapat diterima. Arah koefisien regresi kebijakan dividen yang positif menunjukkan bahwa semakin tinggi kebijakan dividen yang diproksikan dengan Dividend Payout Ratio perusahaan yang dikeluarkan maka akan meningkatkan harga saham dari suatu perusahaan tersebut. Penelitian ini didukung oleh penelitian dari Al Masum (2014) dan Sharif et al (2015), yang mengatakan kebijakan dividen yang di proksikan dengan dividen payout ratio berpengaruh positif dan signifikan, yang menyatakan Investor menganggap dividen tidak hanya sumber pendapatan melainkan cara bagaimana investor menilai sebuah perusahaan tersebut dari segi investasinya.

Kemudian selanjutnya uji analisis regresi linier bergandayang bertujuan untuk menguji interaksi antar beberapa variabel independen penelitian dengan variabel dependen penelitian. Pengolahan data uji analisis regresi linier berganda inimenggunakan program SPSS. Berikut adalah hasil dari uji analisis regresi linier berganda yang disajikan dalam Tabel 4 . 
Tabel 4

Hasil Uji Analisis Regresi Linier Berganda

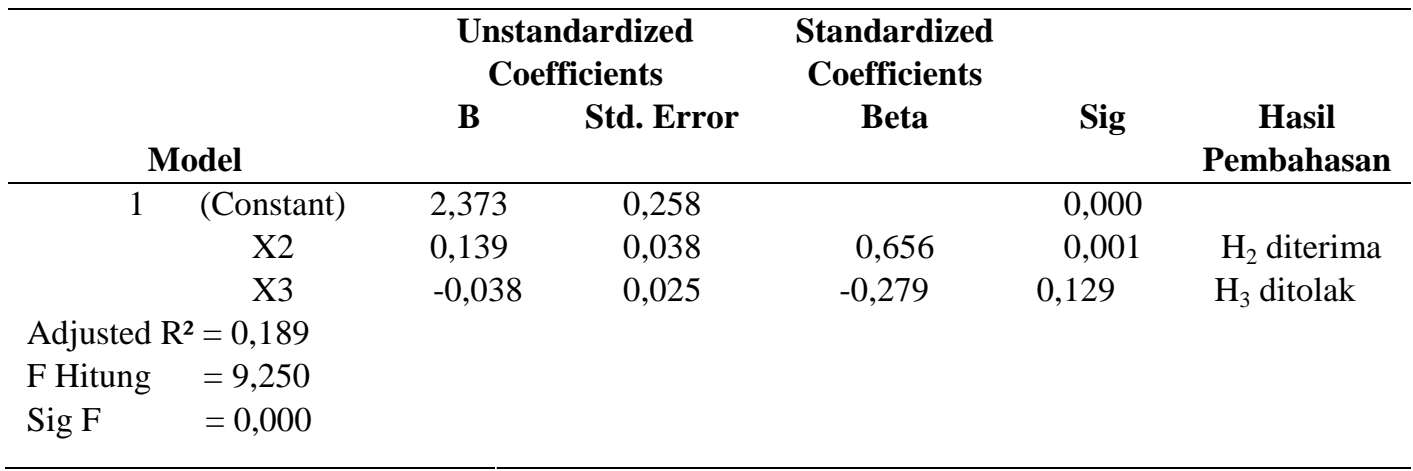

Sumber: Data diolah, 2018

Berdasarkan Tabel 4 maka dapat disimpulkan hasil persamaan regresi sederhana tersebut sebagai berikut.

$$
\mathrm{Y}=2,373+0,139 \mathrm{X}_{2}-0,038 \mathrm{X}_{3}+\mathrm{e}
$$

Nilai konstanta sebesar 2,373 memiliki arti apabila variabel independen konstan yang dimana variabel independen tersebut adalah laba komprehensif perusahaan dan arus kas operasi perusahaan tersebut, maka harga saham setelah tanggal publikasi laporan keuangan naik sebesar 2,373 persen. Nilai koefisien regresi $\mathrm{X}_{2}$ yang merupakan laba komprehensif perusahaan itu sendiri sebesar 0,139 memiliki arti jika laba komprehensif yang dimiliki perusahaan meningkat sebesar 1, maka harga saham setelah tanggal publikasi laporan keuangan akan meningkat sebesar 0,139 persen dengan asumsi variabel independen lainnya konstan. Nilai koefisien regresi $\mathrm{X}_{3}$ yang merupakan arus kas operasi perusahaan itu sendiri sebesar -0,038 memiliki arti jika arus kas operasi perusahaan yang dimiliki meningkat sebesar 1, maka harga saham setelah tanggal publikasi laporan keuangan akan menurun sebesar 0,038 persen dengan asumsi variabel independen lainnya konstan. 
Berdasarkan Tabel 4 diatas maka dapat dilihat juga nilai koefisien determinasi $\left(\mathrm{R}^{2}\right)$, uji kelayakan model (uji F), dan uji hipotesis (uji t) sebagai berikut. Koefisien determinasi $\left(\mathrm{R}^{2}\right)$ diukur untuk mengetahui persentase pengaruh variabel independen terhadap perubahan variabel dependen. Pada Tabel 4 nilai adjusted $\mathrm{R}^{2}$ sebesar 0,189 atau 18,9 persen. Hal ini berarti bahwa variabel harga saham setelah tanggal publikasi laporan keuangan dapat dijelaskan sebesar 18,9 persen oleh variabel laba komprehensif perusahaan dan arus kas operasi perusahaan sedangkan sisanya sebesar 81,1 persen dipengaruhi oleh variabel lain. Uji kelayakan model (Uji F) digunakan untuk mengetahui apakah model analisis regresi linier berganda dalam penelitian ini layak digunakan. Pada Tabel 4 nilai F hitung sebesar 9,250 dengan nilai signifikansi 0,000. Nilai signifikansi tersebut lebih kecil dari level signifikansi 0,05. Jadi dapat disimpulkan bahwa model analisis regresi linier berganda ini layak digunakan.

Kemudian dilakukan uji hipotesis t dimana uji hipotesis (Uji t) digunakan untuk menguji signifikansi masing-masing variabel secara parsial. Berdasarkan Tabel 4 hasil uji t memiliki arti sebagai berikut. Variabel $\mathrm{X}_{2}$ yang merupakan laba komprehensif perusahaan memiliki nilai signifikansi sebesar 0,001 yang berarti lebih kecil dari level signifikansi $\alpha=0,05$. Hal ini menunjukkan bahwa laba komprehensif berpengaruh pada harga saham setelah tanggal publikasi laporan keuangan. Koefisien regresi laba yang menggunakan laba komprehensif perusahaan sebesar 0,139 , sesuai dengan hipotesis yang diharapkan sehingga $\mathrm{H} 2$ dapat diterima. Arah koefisien regresi laba yang positif menunjukkan bahwa 
Arya Bagus Govinda Tedja Bhuana dan I G.N Agung Suaryana. Pengaruh...

semakin tinggi laba yang perusahaan yang dikeluarkan maka akan meningkatkan harga saham dari suatu perusahaan tersebut.

Penelitian ini mendukung penelitian terdahulu oleh Santoso (2014) menyatakan Laba memiliki pengaruh signifikan terhadap harga saham dan arah koefisien dalam penelitian tersebut bertanda positif yang berarti setiap laba bersih meningkatkan satu-satuan akan meningkatkan harga saham, dan penelitian Hiltari (2015) yang menyatakan laba memiliki pengaruh signifikan terhadap harga saham. Kandungan laba yang terdapat dalam laporan laba rugi dapat menunjukkan seberapa baik kinerja suatu perusahaan dan menunjukkan kemampuan perusahaan dalam memberikan pengembalian atas investasi yang dilakukan oleh investor.

Variabel X3 yang merupakan arus kas operasi perusahaan memiliki nilai signifikansi sebesar 0,129 yang berarti lebih besar dari level signifikansi $\alpha=0,05$. Hal ini menunjukkan bahwa arus kas operasi tidak berpengaruh pada harga saham setelah tanggal publikasi laporan keuangan. Koefisien regresi arus kas yang menggunakan arus kas operasi perusahaan sebesar negatif 0,038 , tidak sesuai dengan hipotesis yang diharapkan sehingga H3 ditolak. Variabel arus kas memiliki nilai signifikansi lebih besar dari taraf yang digunakan yaitu 5 persen menunjukkan bahwa arus kas operasi tidak berpengaruh signifikan terhadap harga saham perusahaan setelah tanggal publikasi laporan keuangan.

Peningkatan arus kas operasi menunjukan meningkatnya penghasilan perusahaan sehingga investor tertarik untuk melakukan investasi dan menurunnya arus kas operasi atau arus kas operasi yang negatif suatu perusahaan mengindikasikan perusahaan tersebut belum mampu mengandalkan sumber 
pendanaannya sendiri yang dimana perusahaan perlu membutuhkan sumber pendanaan dari luar, dalam hasil penelitian, arus kas operasi tidak berpengaruh signifikan terhadap harga saham, didukung oleh penelitian oleh penelitian Rhamedia (2015), dan Djago (2016), yang mendapatkan hasil yang sama bahwa arus kas operasi tidak berpengaruh terhadap harga saham, menyatakan dari hasil data yang didapat rata-rata yang berfluktuasi atau tidak meningkat tiap tahunnya ataupun adanya yang minus dari laporan arus kas operasi perusahaan maka kita dapat melihat bahwa laporan arus kas operasi yang tidak stabil ini dapat mengurangi minat para investor untuk tertarik membeli saham pada perusahaan mereka.

Implikasi penelitian ini dibagi atas dua jenis; 1) implikasi teoritis yang menghasilkan simpulan terdapat bukti empiris yang diperoleh dan hasil yang sesuai dengan teori yang dipakai melalui penelitian ini terkait hasil penelitian data yang dilakukan di perusahaan yang tercatat dalam indeks LQ45 secara konsisten periode 2014-2016 yang menunjukkan kebijakan dividend dan laba komprehensif berpengaruh positif dan signifikan terhadap harga saham, arus kas operasi tidak berpengaruh signifikan pada harga saham. 2) implikasi praktis hasil penelitian menjadi bahan pertimbangan bagi calon investor maupun investor dalam mengambil keputusan investasi dengan melihat kebijakan dividen yang dikeluarkan perusahaan dengan menggunakan proksi dividen payout ratio, laba, dan arus kas yang dihasilkan perusahaan perusahaan. Pihak investor hendaknya memperhatikan pula faktor-faktor lain dalam berinvestasi karena dilihat dari 
Arya Bagus Govinda Tedja Bhuana dan I G.N Agung Suaryana. Pengaruh...

kecilnya nilai koefisien determinasi penelitian ditunjukkan bahwa terdapat faktorfaktor lain yang mempengaruhi harga saham perusahaan.

\section{SIMPULAN}

Kesimpulan dari penelitian ini yaitu: 1) Variabel kebijakan dividen yang diproksikan dengan dividend payout ratio berpengaruh positif pada harga saham perusahaan setelah tanggal RUPST periode pada 2014-2016. Hal ini berarti semakin besar kebijakan dividen yang diproksikan dengan dividend payout ratio maka harga saham perusahaan pada saat setelah tanggal RUPST tersebut pun akan meningkat; 2) Variabel laba yang menggunakan laba komprehensif perusahaan berpengaruh positif pada harga saham perusahaan setelah tanggal publikasi laporan keuangan pada periode 2014-2016. Hal ini berarti semakin besar laba yang dihasilkan oleh perusahaan maka harga saham pada saat setelah tanggal publikasi laporan keuangan akan meningkat; 3) Variabel arus kas yang menggunakan arus kas operasi tidak berpengaruh pada harga saham perusahaan setelah tanggal publikasi laporan keuangan periode 2014-2016.

Adapun beberapa hal yang dapat disarankan sesuai dengan hasil pembahasan hingga kesimpulan yang disajikan pada penelitian ini meliputi: 1) Perusahaan yang terdaftar konsisten dalam indeks saham LQ45 di Bursa Efek Indonesia sebaiknya harus mempertahankan kebijakan dividen yang akan dibagikan kepada para pemegang saham, serta perusahaan juga sebaiknya dapat mengelola laba dan arus kas perusahaan dengan baik sehingga dapat meningkatkan harga saham akan suatu perusahaan tersebut. 2) Para investor dan calon investor diharapkan mampu memperhatikan nilai dari rasio dividen payout 
ratio perusahaan, laba dan arus kas perusahaan sebagai bahan pertimbangan dalam berinvestasi didalam pasar modal.3) Penelitian selanjutnya diharapkan mampu memperluas objek penelitian baik dari segi bidang usaha, periode penelitian, maupun jumlah variabel penelitiannya.

\section{REFERENSI}

Ardiprawiro. “Manajemen Keuangan”. Universitas Gunadarma, ATA 2015/2016.

Al Masum, Abdullah. 2014. Dividend Policy and Its Impact on Stock Price - A Study on Commercial Bank Listed in Dhaka Stock Exchange. Global Disclosure of Economic and Business, 3(1), hal.9-17.

Antolis, Teguh dan Dossugi, Samuel. 2008. Pengaruh Fluktuasi IHSG, Inflasi, Dan Suku Bunga Terhadap Imbal Hasil Unit link Berbasis Saham. Journal of Applied Finance and Accounting, 1(1), hal.141-165.

Asrianti dan Syamsuri Rahim. 2013. "Pengaruh Laba Dan Arus Kas Terhadap Harga Saham Perusahaan LQ 45 Di Bursa Efek Indonesia". Jurnal Akuntansi Aktual, 3(1), hal.22-38.

Ball, R.J. and Brown, P. 1968. An empirical evaluation of accounting incomeNumbers. Journal of Accounting Research, 6(2), hal.159-178.

Bhattacharya, Sudipto. 1979. Imperfect Information, Dividend Policy, and the Bird in the Hand Fallacy. The Bell Journal of Economics, 10(1), hal.259270.

Darmadji, Tjiptono dan Fakhruddin, Hendy M. 2001. "Pasar Modal Indonesia: Pendekatan Tanya Jawab". Jakarta: Salemba 4.

Djago, Fransisko Pratama Hendro. 2016. Pengaruh Arus Kas Operasi, Arus Kas Pendanaan, Laba Akuntansi, Nilai Buku, Dan Ukuran Perusahaan Terhadap Perubahan Harga Saham Pada Perusahaan Manufaktur Yang Terdaftar Di BEI. Artikel Ilmiah Sekolah Tinggi Ilmu Ekonomi Perbanas, Surabaya.

Fernandus, Yoakim. 2015. Pengaruh Kebijakan Dividen Terhadap Harga Saham. Skripsi Program Studi Akuntansi pada Fakultas Ekonomi Universitas Sanata Dharma, Yogyakarta.

Gitman, Lawrence, et al. "Fundamentals of Investing". 12th Edition. 
Hiltari, Ni Putu Saka, Sri Rahayu. 2015. Pengaruh Laba Bersih Dan Komponen Arus Kas Terhadap Harga Saham Perusahaan Yang Terdaftar Di Indeks LQ 45 Bursa Efek Indonesia. e-Proceeding of Management, 2(3), hal.34423449 .

Ikatan Akuntansi Indonesia. 2015. "PSAK No.2”.

Indonesian Stock Exchange. IDX Statisitic . Beberapa Tahun Terbit.

Istanti, Sri Layla Wahyu. 2013. Pengaruh Kebijakan Dividen Terhadap Harga Saham Pada Perusahaan LQ45. 19(1), hal.7-13.

Jama'an. 2008. Pengaruh Mekanisme Corporate Governance dan Kualitas Kantor Akuntan Publik Terhadap Integritas Informasi Laporan Keuangan (Studi Pada Perusahaan Publik Di BEJ). Tesis Strata-2 Program Studi Magister Sains Akuntansi pada Universitas Diponegoro, Semarang.

Jogiyanto, Hartono. 2008. "Teori Portofolio dan Analisis Investasi”. Edisi Kelima, BPFE. Yogyakarta.

Junaidi. 2015. Laba dan Arus Kas dalam Memprediksi Laba dan Arus Kas Masa Mendatang dan Pola Harga Saham. Jurnal Akuntansi dan Keuangan, 17(2), hal.97-107.

Kieso, et al. 2011. "Intermediete Accounting". Edisi ke-12. Diterjemahkan oleh Emil Salim. Jakarta: Erlangga.

Maharani, A. A. Istri Agung. 2014. Respon Pasar Atas Informasi Laba (Replikasi Ball Dan Brown 1968). E-Jurnal Akuntansi Universitas Udayana, hal 83-93.

Majanga, Byson B. 2015. The Dividend Effect on Stock Price. Accounting and Finance Research, 4(3), hal.99-105.

Martani, Dwi, et al. (2012). "Akuntansi Keuangan Menengah Berbasis PSAK". Buku 1. Jakarta : Salemba Empat.

Mutia, Evi. 2012. Pengaruh Informasi Laba dan Arus Kas terhadap Harga Saham. Jurnal Akuntansi, 1(1), hal.12-22.

Nurmala. 2006. Pengaruh Kebijakan Dividen terhadap Harga Saham Perusahaanperusahaan Otomotif di Bursa Efek Jakarta. Mandiri, 9(1), hal.17-24.

Rhamedia, Hartika. 2015. Pengaruh Informasi Arus Kas, Laba Akuntansi, dan Ukuran Perusahaan Terhadap Harga Saham (Studi Empiris pada Perusahaan LQ 45 yang Terdaftar di PT. BEI. Skripsi Program Studi Akuntansi pada Fakultas Ekonomi Universitas Negri Padang. 
Samsul, Mohamad. 2006. "Pasar Modal dan Manajemen Portofolio". Surabaya: Erlangga

Santoso, Okky Himawan. 2014. Pengaruh Informasi Laba dan Arus Kas terhadap Harga Saham (Studi pada Perusahaan yang Tercatat di Indeks Sri Kehati Tahun 2010-2012). e-Proceeding of Management, 1(3), hal.255-278.

Schneeman, Angela. 2012. "Law of Corporations and Other Business Organizations". 5th Edition.

Sharif, et al. 2015. Effect of Dividend Policy on Stock Prices. Journal of Management Info, 6(1), hal.55-85.

Subramanyam, KR dan John, J. Wild. 2008. “Analisis Laporan Keuangan”. Edisi Sepuluh McGraw-Hill, New York.

Subramanyam, KR dan John, J. Wild. 2010. “Analisis Laporan Keuangan”. Buku Satu, Edisi Sepuluh, Salemba Empat, Jakarta.

Sugiyono. 2014. "Metode Penelitian Kuantitatif, Kualitatif, dan Kombinasi (Mixed Methods)". Bandung : Alfabeta.

Topowijono, Wahyu Surya Kusumawati. 2016. Pengaruh Profitabilitas, Kebijakan Dividen, dan Risiko Sistematis Terhadap Harga Saham (Studi pada Perusahaan Manufaktur yang Listing di BEI periode 2012-2014). Jurnal Administrasi Bisnis (JAB), 35(2), hal.127-135.

Yocelyn, Azilia dan Jogi Christiawan, Yulius. 2012. Analisis Pengaruh Perubahan Arus Kas dan Laba Akuntansi terhadap Return Saham pada Perusahaan Berkapitalisasi Besar. Jurnal Akuntansi dan Keuangan, 14(2), hal.81-90. 